\title{
PENGEMBANGAN MULTIMEDIA PEMBELAJARAN INTERAKTIF BERBASIS VIDEO MATERI SIKAP CINTA TANAH AIR DAN PEDULI LINGKUNGAN
}

\author{
Irfan Adi Nugroho*, Herman Dwi Surjono \\ Universitas Negeri Yogyakarta. Jl. Colombo No. 1, Depok, Sleman 55281, Indonesia \\ * Corresponding Author. Email: nugroho.kudus@gmail.com \\ Received: 25 September 2017; Revised: 15 May 2019; Accepted: 21 May 2019
}

\begin{abstract}
Abstrak
Penelitian ini memiliki tujuan: (1) menghasilkan multimedia pembelajaran interaktif berbasis video yang layak meningkatkan sikap cinta tanah air dan peduli lingkungan Gugus Gajah Mada, Dawe, Kudus, (2) mengetahui kefektifan multimedia pembelajaran interaktif berbasis video dalam meningkatkan sikap cinta tanah air dan peduli lingkungan di SD kelas V gugus gajah Dawe Kudus dikembangkan. Multimedia yang telah disusun di uji oleh ahli, menggunakan angket dan dihitung menggunakan skala lima, untuk hasil dari sikap cinta tanah air juga menggunakan angket sebagai sara untuk menggali data. Hasil analisis data menunjukkan multimedia yang disusun layak digunakan sebagai media pembelajaran, terbukti dari empat aspek penilaian memperoleh nilai yang berkategori minimal baik. Tampilan 3,93, program 4, 08 pembelajaran 3,71 dan ini 4,20. Uji efektifitas menunjukkan data bahwa media yang telah dikembangkan efektif untuk meninkatkan siap cinta tanah air dan peduli lingkungan, terbukti dari perbandingan cinta tanah air yang tidak menggunakan media memperoleh rata-rata 335,96 dan yang menggunakan media 1107,93 bagi siswa yang menggunakan media. Sikap peduli lingkungan yang tidak menggunakan media memperoleh rata-rata 298,52 dan yang menggunakan media 944,20.
\end{abstract}

Kata kunci: Multimedia interaktif, cinta tanah air, peduli lingkungan

\section{DEVELOPING VIDEO-BASED INTERACTIVE TEACHING MULTIMEDIA IN TERMS OF THE NATIONALISM AND ENVIRONMENTAL AWARENESS}

\begin{abstract}
The purposes of the research are: (1) creating reliable-interactive based video learning multimedia to improve nationalism and environmental awareness of Gajah Mada, Dawe, Kudus Division, (2) finding out its effectiveness to improve nationalism and the awareness. The arrange multimedia is tested by the experts using questionnaire and counted through the use of five scale. In other hand, for nationalism, the use of questionnaire is used to collect data. The data analysis shows the arranged multimedia is reliable to use as learning media, proven from four assessed aspects gets fair minimum category. The scores are appearance 3.93, program 4.08, learning 3.71, the core is 4.20 . Its test of effectiveness shows the developed media is effective to improve the nationalism and the awareness, proven from its comparison compared to those averages of not using the media 335.96, while the one utilizing it 1107.93. The awareness of those not utilizing it gains average 298.52 while the utilizing one 944,20 .
\end{abstract}

Keywords: Interactive multimedia, nationalism, environmental-awereness

doi) http://dx.doi.org/10.21831/jitp.v6.1.15911 


\section{Pendahuluan}

Pendidikan karakter merupakan salah satu hal yang diharapkan untuk dapat membentuk karakter siswa sesuai dengan yang dicanangkan pemerintah untuk mewujudkan karakter bangsa Indonesia. Pendidikan karakter merupakan salah satu visi dari pembangunan nasional yang bertujuan untuk mewujudkan masyarakat berakhlak mulia, bermoral, beretika, berbudaya, dan beradab berdasarkankan falsafal pancasila (Kemendikbud, 2011, p. 5).

Selanjutnya, Lewis, Robinson III, dan Hayes (2011, p. 230) menyatakan bahwa pendidikan karakter harus menjadi iklim norma kebiasaan dalam lingkungan sekolah dan tidak menjadi kebiasaan yang bersifat sementara. Pendidikan karakter dapat mencegah pengaruh-pengaruh buruk yang berkembang di masyarakat. Dalam kehidupan bermasyarakat pendidikan karakter bertujuan sebagai pencegahan perilaku negatif dan dirancang untuk menanggulangi penggunaan narkoba pada remaja, penyimpangan seksual, dan kekerasan di masyarakat. (Harrington, et al., 2001, p.534)

Pembentukan karakter tidak luput dari pembentukan sikap dalam kehidupan sehari-hari, terutama dalam pembentukan mental siswa sekolah dasar. Spencer (Azwar, 2007, p. 5) menyatakan bahwa sikap merupakan status mental seseorang. Sikap mempunyai sifat yang stabil dan berlangsung lama (Walgito, 2002, p. 54). Walaupun sikap memiliki sebuah ketetapan yang berlangsung lama, tidak menutup kemungkinan bahwa sikap dapat berubah karena beberapa faktor. Purnomo dan Wilujeng (2016) mengemukakan sikap peduli ditunjukan setiap siswa pada saat proses pembelajaran, aspek keterampilan terlihat ketika siswa secara aktif dan mandiri mencari contoh-contoh binatang langka dan tidak langka yang ada di lingkungannya, setiap siwa mampu mengklasifikasikan dan menunjukan di depan kelas gambar hewan langka dan tidak langka. Oleh karena itu, pendidikan karakter dan pendidikan sikap tidak dapat terpisahkan. Terdapat 18 karakter yang dikembangkan oleh Kementrian Kebudayaan dan Pendidikan Republik Indonesia, yaitu: religius, jujur, toleransi, disiplin, kerja keras, kreatif, mandiri, demo-krasi, rasa ingin tahu, semangat kebangsaan, cinta tanah air, menghargai prestasi, bersahabat, komunikatif, cinta damai, gemar membaca, peduli lingkungan, peduli sosial, dan tanggung jawab.

Objek dalam rangka mengumpulkan dara awal penelitian ini adalah pada Gugus Gajah Mada, Kecamatan Dawe, Kabupaten Kudus. Pada Gugus Gajah Mada dalam penyampaian pendidikan karakter, guru mengandalkan pembelajaran secara lang-sung dan menggunakan beberapa media. Proses pembelajaran tersebut masih dirasa kurang efektif terutama di dalam materi sikap cinta tanah air dan peduli lingkungan. Kurang-nya sikap cinta tanah air di Gugus Gajah Mada ditunjukkan dengan kurang-nya kehafalan lagu kebangsaan, pendalaman perjuangan para pahlawan, dan kurang siapnya siswa dalam mengikuti upacara.

Susanto (2008) menyatakan bahwa cinta tanah air bukan hanya penghayatan saat upacara bendera saja, tetapi juga pada pelafalan lagu nasional, nama pahlawan beserta perjuangannya, dan menghafal pancasila. Agar kecintaan terhadap tanah air terus berlangsung, maka sejarah tidak boleh dilupakan, seperti yang disampaikan Naim (2012, p. 176) bahwa banyak sejarah yang dilupakan, padahal kemajuan yang diraih suatu bangsa tidak mungkin terwujud tanpa pengorbanan dan jasa para pahlawan. Sikap cinta tanah air penting untuk ditanamkan sejak dini, penanaman cinta tanah air dapat maksimal melalui pembelajaran pendidikan pancasila dan kewarganegaraan (PPKn). Senada dengan hal tersebut Nudji (2015, p. 410) menyatakan bahwa salah satu cara untuk meningkatkan rasa nasionalisme adalah dengan cara pendidikan pancasila dan kewarganegaraan.

Sedangkan dari aspek kepedulian lingkungan, masih banyaknya perilaku 
siswa yang membuang sampah sembarangan, dan kurangnya perhatian terhadap lingkungan kelas serta sekolah. Halhal kecil tersebut jika tidak ditanggapi lebih lanjut dapat menyebabkan siswa memiliki sifat kurang peduli terhadap lingkungan sekitarnya. Diperjelas oleh Naim (2012, p. 200) bahwa pencemaran udara, kerusakan hutan, banjir, kekeringan, dan berbagai persoalan lainnya terjadi diberbagai tempat karena kurangnya rasa kepedulian terhadap lingkungan. Muzanni \& Muhyadi (2016) mengemukakan bahwa dalam pembelajaran diperlukan adanya pengembangan.

Di lain pihak, pengembangan juga tidak luput dari beberapa aspek, terutama pada aspek penggunaan media pembelajaran untuk mencapai tujuan yang diharapkan. Suryansah dan Suwarjo (2016) mengemukakan bahwa media video dapat meningkatkan motivasi belajar siswa, jika motivasi dapat ditingkatkan berarti sikapun dapat ditingkatkan dengan media video. Sikap peduli terhadap lingkungan mempunyai banyak faktor yang dapat berpengaruh terhadap lingkungan, perilaku, kesadaran, pengetahuan dan nilai-nilai yang diterapkan di dalam masyarakat (Aminrad et al., 2010, p.2). Sikap peduli terhadap lingkungan harus menjadi keberlanjutan dan harus diterapkan secara langsung di sekolah, karena sekolah menjadi tempat pendidikan dan pembelajaran bagi setiap siswa (Kusano et al., 2013, p. 30)

Kedua permasalahan tentang sikap cinta tanah air dan peduli lingkungan dapat dipecahkan dengan mengembangkan sebuah multimedia interaktif berbasis video, karena video memiliki beberapa kelebihan dalam menyampaikan informasi pembelajaran. Diantara kelebihan tersebut yaitu multimedia dapat menyimpan banyak materi, sehingga dapat memperkaya sumber referensi pembelajaran siswa. Multimedia merupakan sebuah koleksi materi dalam berbagai paket kerja yang didesain untuk disajikan melalui penggunaan lebih dari satu medium secara terintegrasi (Seels \& Richey, 1994, p. 131).
Multimedia dimaknai sebagai sebuah alat yang dapat dipergunakan dan memiliki beberapa paket materi yang dapat dipilih secara mandiri oleh guru, siswa maupun pengguna umum. Keunggulan lainnya dari multimedia yaitu multimedia merupakan media interaktif yang dapat mempermudah siswa dalam mempelajari materi pembelajaran yang disajikan yaitu inisiasi, respon dan umpan balik (Evans \& Gibbons, 2007; Surjono, 2017). Penggunaan media dapat menyelesaikan masalah peserta didik melalui gaya belajar yang berbeda pada setiap peserta didik (Sakat et al., 2012, p. 876).

Pengembangan multimedia harus memiliki patokan sehingga hasil maksimal dapat terwujud. Tahapan tersebut disusun berdasarkan pendapat para ahli, diantaranya adalah Luther (Sutopo, 2003, p. 3248) bahwa terdapat enam tahapan dalam mengembangkan multimedia, yaitu: (1) Concept, (2) Design, (3) Material Collecting, (4) Assembly, (5) Testing, dan (6) Distribution. Rumusan masalah dalam penelitian ini adalah (1) Bagaimana multimedia pembelajaran interaktif berbasis video yang layak dalam peningkatan sikap cinta tanah air dan peduli lingkungan siswa kelas V SD di Gugus Gajah Mada, Dawe, Kudus?, (2) Seberapa efektif multimedia pembelajaran interaktif berbasis video terhadap peningkatan sikap cinta tanah air dan peduli lingkungan pada siswa kelas V SD di Gugus Gajah Mada, Dawe, Kudus?.

Adapun tujuan dalam penelitian ini adalah: (1) menghasilkan multimedia pembelajaran interaktif berbasis video yang layak dalam meningkatkan sikap cinta tanah air dan peduli terhadap lingkungan di SD kelas V Gugus Gajah Mada, Dawe, Kudus, (2) Mengetahui keefektifan multimedia pembelajaran interaktif ber-basis video dalam meningkatkan sikap cinta tanah air dan peduli terhadap lingkungan di SD kelas V Gugus Gajah, Dawe, Kudus yang dikembangkan. 


\section{Metode Penelitian}

Jenis Penelitian

Jenis penelitian ini merupakan model penelitian dan pengembangan (research and development) yang memiliki tujuan untuk mengembangkan multimedia pembelajaran interaktif berbasis video. Materi yang termuat dalam penelitian ini adalah sikap cinta tanah air dan peduli lingkungan untuk siswa kelas V Sekolah Dasar.

Tempat dan Waktu Penelitian

Penelitian ini dilaksanakan pada semester kedua tahun pelajaran 2016/2017, dimulai dari pengambilan data awal pada saat semester pertama. Pelaksanaan uji coba awal, uji coba lanjutan dan ujii coba operasional dilakukan pada bulan April-Mei 2017. Penelitian bertempat di Gugus Gajah Mada, Desa Kandangmas, Kecamatan Dawe, Kabupaten Kudus. Adapun sekolah dasar yang menjadi tempat dilangsungkannya penelitian ini adalah SD 1 Kandangmas, SD 3 Kandangmas dan SD 4 Kandangmas. Ketiga SD tersebut menjadi subjek penelitian dan pengembangan dikarenakan di Gugus Gajah Mada memiliki beberapa permasalahan, seperti kurangnya penanaman sikap cinta tanah air dan peduli lingkungan.

\section{Subjek Penelitian}

Subjek uji coba dalam penelitian pengembangan ini adalah sebanyak 59 siswa sekolah dasar kelas V. dari ke 59 siswa tersebut terdiri dari 15 siswa kelas V SD 1 Kandangmas, 26 siswa kelas V SD 3 Kandangmas dan 18 Siswa SD 4 Kandangmas. Ketiga Sekolah Dasar tersebut merupakan sekolah yang berada pada Gugus Gajah Mada, Kandangmas, Dawe, Kudus.

\section{Prosedur Penelitian}

Prosedur penelitian dan pengembangan dalam penelitian ini mengadaptasi dari Borg \& Gall (1983) yang terdiri dari sepuluh tahap pengembangan yaitu: (1) penelitian dan pengumpulan informasi, (2) perencanaan produk, (3) pengembangan draf produk, (4) uji coba awal, (5) revisi hasil uji coba awal, (6) uji coba lapangan, (7) penyempurnaan produk hasil uji coba lapangan, (8) uji lapangan, (9) revisi produk akhir, (10) diseminasi atau implementasi.

Studi pendahuluan dilakukan dengan studi pustaka, sedangkan studi lapangan dilakukan dengan mengumpulkan informasi sebanyak-banyaknya dari sekolah dasar yang berada di Gugus Gajah Mada, Dawe, Kudus. Setelah melakukan studi pendahuluan, dilakukanlah pengembangan produk awal, dimulai dari perumusan materi, pembuatan storyboard, dan pengem-bangan produk. Tahapan setelah multi-media selesai dikembangkan ialah dengan melakukan uji penilaian ahli media dan ahli materi untuk mendapatkan masukan revisi guna mengevaluasi produk. Tahapan beri-kutnya setelah mendapat penilaian dari para ahli adalah melakukan pengujian awal dengan melibatkan 3 orang responden yang diambil dari siswa SD 3 Kandangmas. Pada tahap ini peneliti memberikan pengarahan tentang penggunaan produk multimedia kepada responden, sehingga responden dapat menjalankan produk dengan baik. Selanjutnya, dilakukanlah pengujian penggunaan terhadap produk untuk memperoleh data evaluasi yang digunakan untuk merevisi produk.

Setelah produk selesai direvisi pada tahap pengujian awal, maka dilakukanlah pengujian tahap kedua, yaitu uji coba lapangan dengan melibatkan 5 orang responden yang diambil dari siswa kelas V SD 3 Kandangmas. Tahapan pelaksanaanya sama dengan pelaksanaan pengujian awal dan dilakukan revisi berdasarkan hasil evaluasi yang didapatkan. Tahapan utama dalam pengujian ini adalah tahapan pengujian operasional yang melibatkan 59 responden dari siswa kelas V Sekolah Dasar Gugus Gajah Mada, Dawe, Kudus. Responden tersebut terbagi dalam dua kelas, yaitu kelas eksperimen yang terdiri dari 41 
siswa dan kelas kontrol yang terdiri dari 18 siswa.

Desain penelitian ini menggunakan quasi experiment dengan desain Intact-Group Comparison. Pengambilan data menggunakan quasi experiment dengan berpacu pada dua kelas, yaitu kelas kontrol dan kelas eksperimen. Kelas kontrol adalah kelas tanpa mendapatkan perlakuan, yaitu kelas yang tidak menggunakan produk multimedia yang telah dikembangkan dalam penyampaian materi sikap cinta tanah air dan peduli lingkungan, serta kelas eksperimen yaitu kelas yang mendapatkan perlakuan dengan penggunaan multimedia pembelajaran interaktif yang telah dikembangkan.

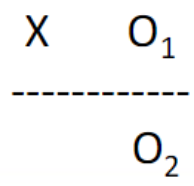

Keterangan:

$\mathrm{X}$ : treatment

$\mathrm{O}_{1} \quad$ : hasil post-test kelompok eksperimen

$\mathrm{O}_{2} \quad$ : hasil post-test kelompok kontrol

Teknik Analisis Data

Teknik analisis data yang digunakan untuk menilai keberhasilan multimedia ini adalah dengan menggunakan angket yang diberikan lima pilihan penilaian yaitu, sangat baik " 5 ", baik " 4 ", cukup baik " 3 ", kurang baik "2", dan sangat kurang baik, " 1 ".

\section{Hasil dan Pembahasan}

Hasil

Analisis kebutuhan dilakukan dengan melakukan studi pendahuluan, yaitu studi pustaka dengan cara menyusun indikator cinta tanah air dan peduli lingkungan. Indikator pada materi cinta tanah air yaitu: (1) memahami posisi geografis wilayah Rapublik Indonesia dalam perhubungan laut dan udara dengan negara lain, (2) menyenangi budaya dan seni di Indonesia, (3) menyenangi keragaman su$\mathrm{ku}$, etnis, dan bahasa sebagai keunggulan yang hadir di wilayah Negara Indonesia, (4) menyenangi sumbangan produk pertanian, perikanan, flora dan fauna Indonesia, dan (5) mengetahui peran laut dan hasil laut Indonesia bagi dunia. Data tersebut diperoleh dari kajian pustaka dan standar pendidikan karakter. Standar dari pendidikan karakter dipilih karena dalam penerapannya, sekolah tidak dapat lepas dari standar yang telah dibuat oleh pemerintah. Adapun pengembangan materi dilakukan dengan melihat faktor internal dan eksternal. Faktor yang memengaruhi dipilihnya standar tersebut terdapat pada pentingnya mengikuti standar nasional yaitu pada kebutuhan di lapangan.

Indikator yang telah tersusun tersebut tidak serta merta langsung dipergunakan, karena perlu diadakan penjabaran dari indikator tersebut. Indikator mengagumi posisi geografis wilayah Indonesia dalam perhubungan laut dan udara dengan negara lain, dipecah dalam lima sub indikator, yaitu: (a) saya mengetahui perbatasan dengan negara lain yang berupa daratan, (b) saya mengetahui perbatasan dengan negara lain yang berupa lautan, (c) saya mengetahui perbatasan dengan negara lain yang berupa udara, (d) saya mengetahui posisi geografis negara diantara dua benua, (e) saya mengetahui posisi geografis negara diantara dua samudera.

Indikator kedua, mengagumi budaya dan seni di Indonesia dijabarkan dalam sub indikator menjadi, (a) saya senang dengan kekayaan budaya Indonesia, (b) saya senang dan akan men-jaga kesenian yang ada di Indonesia, (c) saya akan menjaga kekayaan budaya Indonesia terutama budaya yang ada di daerah saya, (d) saya akan merawat budaya, sehingga tidak tergusur oleh bangsa luar; (e) saya senang menjaga seni peninggalan sejarah Indonesia agar tidak rusak.

Indikator ketiga, yaitu mengagumi keragaman suku, etnis, dan bahasa sebagai keunggulan yang hadir di wilayah negara Indonesia dibagi menjadi lima sub: (a) saya senang menjaga keberagaman negara 
Indonesia, (b) saya senang menggunakan bahasa Indonesia sebagai bahawa persatuan tanpa menghilangkan budaya yang ada di Indonensia, (c) saya mengerti keunggulan negara Indonesia dengan negara lain, (d) saya akan menjaga persatuan dan kesatuan agar tdak menjadi perpecahan karena keberagaman, dan (e) saya tidak memilih-milih teman karena perbedaan.

Indikator keempat, mengagumi sumbangan produk pertanian, perikanan, flora dan fauna Indonesia dipecah menjadi sub indikator, yaitu: (a) saya senang menggunkan produk pertanian Indonesia, (b) saya senang menggunakan produk perikanan Indonesia, (c) saya senang menggunakan produk-produk nabati dari Indonesia, (d) saya senang menggunakan produk-produk hewani dari Indonesia, (e) saya akan menjaga dan melestarikan produk pertanian, perikanan di Indonesia.

Indikator kelima, mengagumi peran hutan Indonesia bagi dunia dibagi menjadi sub indikator, yaitu: (a) saya akan menjaga hutan Indonesia, (b) saya mengerti peran hutan, (c) saya mengagumi besarnya hutan Indonesia, (d) saya akan menanam pohon untuk menjaga pelestarian hutan, (e) saya senang dengan hutan sebagai sumber oksigen. Dan indikator terakhir dari materi sikap cinta tanah air adalah mengagumi laut dan hasil laut Indonesia dari bangsabangsa di dunia, dipecah dalam sub indikator, yaitu: (a) saya akan menjaga laut Indonesia, (b) saya akan ikut serta menjaga hasil laut Indonesia, (c) saya akan ikut melestarikan laut Indonesia, (d) saya mengerti peran laut sebagai sumber perikanan Indonesia, dan (e) saya senang menjaga laut Indonesia dan dipergunakan sebagaimana mestinya.

Indikator peduli lingkungan terdiri dalam lima aspek yaitu: (1) membersihkan WC, (2) membersihkan tempat sampah, (3) membersihkan lingkungan sekolah, (4) memperindah kelas dan sekolah dengan tanaman, dan (5) ikut memlihara taman di halaman sekolah. Studi lapangan dilakukan dengan mencari kebutuhan akan media yang dibutuhkan oleh guru, yaitu media yang belum dimilki oleh sekolah dalam menyampaikan materi tentang sikap peduli lingkungan. Analisis kebutuhan di lapangan tersebut dilihat dalam aspek fisik yang melihat bagaimana materi dan media yang telah disusun nantinya dapat dipergunakan dengan baik dan sesuai dengan kebutuhan.

Indikator yang diperoleh dari sikap peduli lingkungan dibagi menjadi sub-sub indikator. Indikator membersihkan WC terbagi menjadi lima sub indikator, yaitu: (a) saya senang menjaga kebersihan $\mathrm{WC},(\mathrm{b})$ saya tidak senang melihat WC yang kotor, (c) saya selalu menyiram dengan air setelah menggunakan $\mathrm{WC}$, (d) saya selalu menyiram dengan air setelah menggunakan WC, (e) saya akan menutup pintu WC setelah menggunakan agar tetap bersih. Indikator kedua, membersihkan tempat sampah dibagi menjadi sub indikator sebagai berikut: (a) saya senang membersihkan tempat sampah didepan kelas, (b) saya menepati jadwal piket membersihkan tempat sampah, (c) saya menepati jadwal piket membersihkan tempat sampah, (d) saya ikut membakar sampah yang ada di penampungan sampah, (e) saya akan menjadi contoh kepada teman-teman dalam membersihkan sampah.

Indikator ketiga, membersihkan lingkungan sekolah dibagi menjadi sub indikator: (a) saya senang membersihkan lingkungan sekolah, (b) saya akan mengusulkan kepada guru jadwal membersihkan lingkungan sekolah jika belum ada, (c) saya akan menjadi pelopor dalam membersihkan lingkungan sekolah, (d) saya akan menjaga lingkungan sekolah dimulai dari kelas, (e) saya akan mengambil sampah yang jatuh tidak di tempat sampah.

Indikator keempat, memperindah kelas dan sekolah dengan tanaman dibagi kedalam sub indikator, yaitu: (a) saya menyumbangkan bunga didalam pot untuk diletakkan di depan kelas, (b) saya akan menjaga kelasku terlihat indah dengan bunga dan tanaman, (c) saya akan menanam bunga di lingkungan sekolah, (d) saya akan menanam pohon obat obatan di lingkungan sekolah, (e) saya akan merawat 
dan menyiram setiap hari. Dan yang terakhir indikator ikut serta memlihara taman di halaman sekolah, diuraikan menjadi sub indikator sebagai berikut: (a) saya akan mnyiram setiap hari, (b) saya akan memotong daun-daun agar rapi, (c) saya akan ikut memotong rumput di taman, (d) saya akan memberikan pupuk seminggu sekali, (e) saya akan mengganti bunga baru ketika ada yang layu atau mati.

Hasil dari studi lapangan menunjukkan hasil bahwa sekolah belum memiliki multimedia berbasis video terutama media yang mengajarkan nilai karakter. Akan tetapi sekolah tersebut memiliki sarana/alat yang dapat dipergunakan untuk melaksanakan pembelajaran menggunakan multimedia pembelajaran. Pada tahap selanjutnya, dibuatlah storyboard unutk menjadi acuan dalam mengembangkan multimedia.

Hasil Kelayakan Produk

Kelayakan produk dilakukan oleh ahli media dan ahli materi. Penilaian terbagai dalam empat aspek yaitu, aspek tampilan, aspek pemrograman, aspek pembelajaran dan aspek isi atau materi. Penilaian aspek tampilan meliput: (a) pemilihan dan ukuran font, (b) penggunaan jarak, baris, alinea, dan karakter, (c) keterbacaan teks, (d) tampilan gambar, (e) penggunaan animasi, (f) tampilan video, (g) kejelasan narasi, (h) pilihan background musik, (i) kerapian tampilan slide, (f) keserasian warna background dengan teks, (g) kejelasan warna teks, dan (h) konsistensi penyajian.

Penilaian pada aspek perograman, meliputi: (a) tingkat interaktivitas siswa dengan media, (b) kemudahan memilih menu sajian, (c) kebebasan memilih menu sajian, (d) kemudahan dalam penggunaan, (e) kemudahan navigasi, (f) ketepatan penggunaan tombol, (g) konsistensi penempatan tombol, (h) kejelasan petunjuk penggunaan media, (i) efisiensi teks, dan (j) efisiensi gambar.

Penilaian pada aspek pembelajaran meliputi: (a) kejelasan indikator keberhasilan, (b) kemudahan memahami materi, (c) keruntutan penyajian materi, (d) Kejelasan petunjuk belajar, (e) pemberian motivasi, (f) pemberian contoh, (g) pemberiahan latihan untuk pemahaman materi, (h) pem-berian kesempatan kepada siswa untuk berlatih sendiri, (i) pemberian penguatan untuk jawaban yang benar, (j) pemberian balikan untuk jawaban yang salah, (k) sistematika penyajian materi, (l) kejelasan petunjuk mengerjakan tes, $(\mathrm{m})$ kualitas tes dan penilaiannya, serta (n) keseimbangan materi dengan soal tes.

Tabel 1. Hasil Uji Validasi Ahli

\begin{tabular}{lllll}
\hline & N & Min. & Max. & Mean \\
\hline Tampilan & 14 & 3 & 5 & 3,93 \\
Pemrograman & 12 & 3 & 5 & 4,08 \\
Pembelajaran & 14 & 2 & 5 & 3,71 \\
Isi & 15 & 4 & 5 & 4,20 \\
Valid N & 12 & & & \\
\hline
\end{tabular}

Dalam melakukan penilaiannya, ahli media dan ahli materi menggunakan Skala Likert yang menggunakan skala lima dengan rentang nilai satu sampai dengan lima. Nilai lima memiliki nilai tertinggi sedangkan satu memiliki nilai terendah. Dari penilian ahli media dan materi tersebut, aspek tampilan memperoleh rata-rata nilai 3,93 dengan kategori baik, aspek pemrograman memperoleh rata-rata nilai 4,08 dengan kategori baik, aspek pembelajaran memperoleh rata-rata nilai 3,71 dengan kategori baik, dan aspek isi memperoleh rata-rata nilai 4,20 dengan kategori baik, sehingga dapat disimpulkan bahwa multimedia pembelajaran yang dikembangkan dinyatakan layak untuk digunakan sebagai media pembelajaran, serta dapat diujicobakan di lapangan.

Uji coba lapangan dapat dikerjakan apabila penilaian dari para ahli memperoleh nilai minimal dengan kateogri baik, sehingga dari hasil tersebut dapat dilanjutkan ke dalam tahapan penelitian selanjutnya (Borg \& Gall, 1983). Media yang telah dinyatakan layak diujicobakan kepada 5 orang responden diambil dari siswa kelas $\mathrm{V}$ SD 3 Kandangmas, Gugus Gajah Mada, Dawe, Kudus. Hasil uji coba dari kelima 
responden tersebut dapat dilihat pada tabel 2.

Tabel 2. Data Hasil Respon Siswa

\begin{tabular}{lllll}
\hline & N & Min. & Max. & Mean \\
\hline Tampilan & 5 & 4 & 5 & 4,47 \\
Pemrograman & 5 & 4 & 5 & 4,43 \\
Pembelajaran & 5 & 4 & 5 & 4,55 \\
Isi & 5 & 4 & 5 & 4,52 \\
Valid N & 5 & & & \\
\hline
\end{tabular}

Dari hasil uji coba terhadap siswa memperoleh data yang signifikan jika dibandingkan dengan hasil penilaian ahli. Pada aspek tampilan, uji coba terhadap siswa memperoleh rata-rata nilai 4,47 dengan kategori sangat baik, aspek pemrograman 4,43 dengan kategori sangat baik, aspek pembelajaran 4,55 dengan kategori sangat baik dan aspek isi 4,52 dengan kategori sangat baik. Setelah proses pengujian terhadap 5 orang responden yang berasal dari siswa kelas V SD 3 Kandangmas selesai dilaksanakan, selanjutnya dilakukan uji coba lapangan untuk mengetahui tingkat keefektifan dari produk multimedia pembelajaran interaktif berbasis video yang telah dikembangkan.

\section{Data Hasil Keefektifan Produk}

Pengujian keektifan dilakukan melalui beberapa tahapan, tahapan pertama dilakukan dengan pengujian normalitas data. Pengujian normalitas data sangat penting guna mengetahui keefektifan media, terutama pada penggunaan rumus perhitungannya, karena setiap rumus perhitungan memiliki spesifikasi produk yang berbeda-beda. Adapun hasil uji normalitas data materi sikap cinta tanah air dapat dilihat pada Tabel 3. Dari hasil pengujian normalitas materi cinta tanah air menunjukkan bahwa data yang diperoleh tidak normal karena data yang tidak menggunakan multimedia pembelajaran adalah 0,000 dengan Kolmogorov-smirnov 4.757, sedangkan yang menggunakan multimedia pembelajaran 0,0000 dengan kolmogorovsmirnov 10.883. Terjadi perbedaan yang signifikan pada siswa yang menggunakan media dengan yang tidak menggunakan media dalam materi sikap cinta tanah air.

Tabel 3. Hasil Uji Normalitas Data

Sikap Cinta Tanah Air

\begin{tabular}{cccc}
\hline $\begin{array}{c}\text { Kelompok } \\
\text { Sampel }\end{array}$ & $\begin{array}{c}\text { Kolmogov- } \\
\text { Smirnov }\end{array}$ & $\begin{array}{c}\text { Asymp. } \\
\text { Sig }\end{array}$ & Ket. \\
\hline $\begin{array}{c}\text { Tanpa } \\
\text { media }\end{array}$ & 4.757 & 0.000 & Tidak \\
Pakai & 10.883 & 0.000 & $\begin{array}{c}\text { Normal } \\
\text { Tidak } \\
\text { Media }\end{array}$ \\
\hline
\end{tabular}

Tabel 4. Hasil Uji Normalitas Data

Sikap Peduli Lingkungan

\begin{tabular}{llll}
\hline $\begin{array}{l}\text { Kelompok } \\
\text { Sampel }\end{array}$ & $\begin{array}{l}\text { Kolmogov- } \\
\text { Smirnov }\end{array}$ & $\begin{array}{l}\text { Asymp. } \\
\text { Sig }\end{array}$ & Ket. \\
\hline $\begin{array}{l}\text { Tanpa } \\
\text { Media }\end{array}$ & 4.911 & 0.000 & $\begin{array}{l}\text { Tidak } \\
\text { Normal } \\
\text { Pakai }\end{array}$ \\
Media & 10.262 & 0.000 & $\begin{array}{l}\text { Tidak } \\
\text { Normal }\end{array}$ \\
\hline
\end{tabular}

Uji normalitas pada materi sikap peduli lingkungan tanpa menggunakan media sebesar 0,000 dengan nilai Kolmogorov-smirnov 4,911 dan menggunakan media sebesar 0,000 dengan nilai kolmogorov-smirnov 10,262. Perolehan perhitungan tersebut menyimpulkan bahwa terdapat ketidak normalan data. Data yang tidak normal dapat dihitung menggunakan rumus Mann Whitney $U$ test. Rumus tersebut dipergunakan untuk menghitung tingkat beda dari penggunaan multimedia pembelajaran interaktif, serta untuk mengetahui seberapa banyak perbedaan dari siswa yang menggunakan multimedia pembelajaran interaktif dengan siswa yang tidak menggunakan media tersbut.

Perbedaan pengaruh sikap cinta tanah air terhadap peningkatan sikap cinta tanah air siswa menggunakan uji Mann Whitney U dapat dilihat pada tabel 5. Tabel 5 menunjukkan rata-rata peringkat tiap kelompok, yaitu pada kelompok pertama rata-rata peringkatnya adalah 335,96 atau lebih rendah daripada rata-rata peringkat kedua, yaitu 1107,93. Dari data yang ditunjukkan pada Tabel 5 dapat dikategorikan bahwa terdapat perbedaan antar siswa yang 
menggunakan media pembelajaran dengan siswa yang tidak menggunakan media. Perbedaan yang mencolok terdapat pada rata-rata hasil penggunaan media dan yang tidak menggunakan media.

Tabel 5. Mann Whitney U Test Rank Media Cinta Tanah Air

\begin{tabular}{lcccc}
\hline & Kel. & $\mathrm{N}$ & $\begin{array}{c}\text { Mean } \\
\text { Rank }\end{array}$ & $\begin{array}{c}\text { Sum of } \\
\text { Rank }\end{array}$ \\
\hline & $\begin{array}{l}\text { Tanpa } \\
\text { media } \\
\text { dengan }\end{array}$ & 510 & 335.96 & 1713330.50 \\
$\begin{array}{l}\text { tanah } \\
\text { air }\end{array}$ & $\begin{array}{l}\text { media } \\
\text { Total } \\
\text { data }\end{array}$ & 1260 & 1107.93 & 1395995.50 \\
\hline
\end{tabular}

Hasil dari Uji Mann Whitney U penggunaan media cinta tanah air terhadap peningkatan sikap cinta tanah air siswa kelas V SD dapat dilihat pada tabel 6 .

Tabel 6. Hasil Uji Mann Whitney terhadap peningkatan sikap cinta tanah air

\begin{tabular}{ll}
\hline & Cinta tanah air \\
\hline Mann-Whitney U & 41034.500 \\
Wilcoxon W & 171339.500 \\
Z & -30.030 \\
Asymp. Sig. (2- tailed) & \\
\hline
\end{tabular}

Pada Tabel 6 menunjukkan bahwa nilai U dalam nilai pada perhitungan MannW U adalah sebesar 41034,500 dan nilai $W$ atau Wilcoxon W adalah sebesar 171339,500. Apabila data tersebut dikonversikan terhadap nilai $Z$, maka diperoleh hasil sebesar -30,030. Nilai Sig atau P Value mendapat nilai $0,000<0,05$. Apabila nilai $p$ value $<$ batas kritis 0,05 , maka terdapat perbedaan bermakna antara dua kelompok atau yang berarti H1 diterima. Dengan demikian penerapan sikap cinta tanah air siswa berbeda antara siswa yang menggunakan media dengan tanpa media.

Pengembangan multimedia yang telah dilaksanakan tersebut tidak hanya dalam satu materi, akan tetapi terdapat dua materi, materi pertama yaitu pada sikap cinta terhadap tanah air dan yang kedua adalah sikap peduli lingkungan. Perbedaan pengaruh untuk penyerapan materi sikap peduli terhadap lingkungan antara siswa yang menggunakan media dengan yang tidak menggunakan media dengan menggunakan uji Mann Whitney dapat dilihat pada Tabel 7.

Tabel 7. Mann Whitney U test Rank Media Peduli lingkungan

\begin{tabular}{rrrrr}
\hline & Kel. & N & $\begin{array}{r}\text { Mean } \\
\text { Rank }\end{array}$ & Sum of Rank \\
\hline $\begin{array}{c}\text { Peduli } \\
\text { lingku- } \\
\text { ngan }\end{array}$ & $\begin{array}{l}\text { Dedia } \\
\text { Dengan }\end{array}$ & 450 & 298,52 & 134336,00 \\
$\begin{array}{l}\text { media } \\
\text { Total } \\
\text { data }\end{array}$ & 1050 & 944,20 & 991414,00 \\
\hline
\end{tabular}

Tabel 7 menunjukkan rata-rata peringkat tiap kelompok, yaitu pada kelompok pertama rata-rata peringkatnya adalah 298,52 lebih rendah daripada rata-rata peringkat kedua, yaitu 944,20. Dari hasil tersebut terdapat perbedaan yang signifikan antara siswa yang menggunakan media pembelajaran dengan siswa yang tidak menggunakan media pembelajaran. Hasil dari uji Mann Whitney $U$ penggunaan media peduli lingkungan terhadap peningkatan sikap peduli dapat dilihat pada tabel 8.

Tabel 8. Hasil Uji Mann Whitney terhadap peningkatan sikap pedul lingkungan

\begin{tabular}{ll}
\hline & Peduli lingkungan \\
\hline Mann-Whitney U & 32861,000 \\
Wilcoxodn W & 134336,000 \\
Z & $-27,654$ \\
Asymp. Sig. (2- tailed) &, 000 \\
\hline
\end{tabular}

Tabel 8 memperlihatkan hasil bahwa hasil nilai Mann- W U mempunyai nilai se-besar 32861,00 dan nilai Wilcoxon $W$ se-besar 134336,00. Data tersebut jika dilakukan konversi terhadap nilai $\mathrm{Z}$ maka diperoleh nilai $-27,654$. Nilai Sig atau $P$ Value sebesar $0,000<0,05$. Apabila nilai $\mathrm{p}$ value $<$ batas kritis 0,05 maka memperoleh perbedaan makna antara dua kelompok, se- 
hingga dapat disimpulkan kalau $\mathrm{H} 1$ diterima. Dengan demikian varians hasil sikap peduli lingkungan siswa antara siswa yang tidak menggunakan media dengan siswa yang menggunakan media adalah tidak sama atau memiliki perbedaan yang sangat signifikan. Nilai tersebut dalam pengujian (t-test)/ nilai rata-rata yang sebagai acuan pada nilai-nilai yang terdapat pada kolom baris yang memiliki asumsi varians disimpulkan bahwa data tersebut tidak sama.

Keterangan tersebut menunjukkan bahwasanya media pembelajaran memberikan perbedaan dampak dalam penyampaian dan pemahaman materi pembelajaran, serta perbedaan dari siswa yang menggunakan media pembelajaran dengan yang tidak menggunakan. Dengan adanya penelitian ini, maka dapat disimpulkan bahwa dengan pengembangan multimedia pembelajaran yang kompeten dan efektif, maka akan meningkatkan proses dan hasil pembelajaran yang akan dicapai oleh siswa.

\section{Pembahasan}

da-pat menunjukkan $\begin{gathered}\text { Multimedia yang dikembangkan } \\ \text { keefektifitasan }\end{gathered}$
dikarena-kan di dalam multimedia tersebut mengan-dung beberapa unsur yaitu: (1) media yang dikembangkan memberikan contoh nyata kepada siswa tentang sikap cinta tanah air yang dapat dicontoh, (2) multimedia tersebut bermuatan video dan mendiskripsikan contoh nyata dengan gambar atau animasi tentang bagaimana cinta tanah air dan peduli terhadap lingkungan, (3) terjadinya interaksi antara multimedia pembelajaran dengan siswa, diantaranya pertanyaan yang dijawab secara langsung dan terkoreksi, (4) contoh materi yang termuat di dalam multimedia diangkat dari berbagai tempat, tidak hanya di sekitar sekolah, melainkan di lingkungan masya-rakat, (5) adanya narasi pada video atau animasi yang disajikan, sehingga siswa tidak hanya sekedar membaca materi yang termuat di layar monitor, (6) diberikan dialog antar tokoh, bagaimana tokoh yang mencontohkan pemborosan air dan sebaliknya, (7) memberikan kesempatan kepada siswa tentang masing-masing gaya belajar yang diadaptasi oleh siswa.

Berikut adalah temuan uji coba produk: (1) respon guru terhadap produk multimedia baik karena sesuai dengan kebutuhan, (2) respon peserta didik terhadap multimedia baik karena tugas yang diberikan sesuai dengan pengalaman peserta didik baik dalam lingkungan sosial maupun lingkungan sekolah, (3) kegiatan pembelajaran lebih menekankan pada kegiatan peserta didik dalam menggunakan stategi-strategi pemecahan masalah terhadap masalah yang disajikan, (4) ketercapaian hasil belajar kognitif yang diperoleh peserta didik.

Aspek tampilan dikembangkan dengan alur cerita yang runtut, gerak animasi sederhana yang dapat mendukung proses pemahaman siswa, dan juga memuat teks, gambar, warna serta audio. Penyusunan tampilan tersebut telah disesuaikan dengan anak usia sekolah dasar kelas V. Aspek pemrograman mencakup beberapa hal, yaitu kemudahan akses siswa dalam mengoperasikan multimedia pembelajaran, kemudahan navigasi, pemberian feedback, dan interaksi siswa terhadap media pembelajaran. Aspek Pembelajaran men-cakup tentang pemberian motivasi, penyajian materi, pemberian contoh dan kejelasan petunjuk penggunaan media. Aspek isi menjadi hal dasar dalam multimedia, karena pengembangan multimedia terletak pada materinya, yaitu tentang bagaimana materi/konsep yang diajarkan harus sesuai, kualitas materi dan kesesuaian materi terhadap siswa.

Dalam mengembangkan multimedia yang baik perlu menekankan karakteristik agar multimedia yang dikembangkan dapat menjadi media yang interaktif dan sesuai dengan kebutuhan siswa. Materi yang disajikan dalam multimedia ini ditampilkan dalam bentuk poinpoin yang dapat dipilih sesuai dengan kebutuhan siswa, serta pemberian simulasi dalam bentuk video pembelajaran yang 
bertujuan memberikan contoh nyata tentang bagamana praktik sikap cinta tanah air dan peduli lingkungan dikehidupan seharihari.

Media pembelajaran interaktif dapat dinyatakan layak serta dapat dipergunakan dalam penelitian lapangan apabila media pembelajaran tersebut telah memenuhi dasar-dasar penilaian oleh ahli materi dan ahli media. Multimedia harus dapat menstimulasi pembelajaran, sehingga dapat diterima oleh siswa, terdapat informasi pembelajaran, mempresentasikan materi secara jelas dan lengkap, serta adanya umpan balik (Gagne, Briggs \& Wager , 1991, p. 11). Selain ini, multimedia pembelajaran dapat dinyatakan layak apabila dapat mening-katkan motivasi dan ketertarikan belajar peserta didik (Chen \& Chung, 2011, p. 920).

Multimedia pembelajaran yang telah dikembangkan dapat dinyatakan efektif karena adanya interaksi antara multimedia dengan siswa. Interaksi yang terjadi di dalam multimedia menjadi keunggulan utama media ini, rambu-rambu agar dapat mencapai interaksi tersebut telah sesuai dengan pendapat Thorn (Munir, 2009) yaitu: (1) kemudahan navigasi, (2) kan-dungan kognisi, (3) adanya presentasi infor-masi, (4) integritas media, (5) artistic dan estetika, (6) fungsi secara keseluruhan. Keenam rambu-rambu tersebut termuat didalam multimedia yang telah peneliti kembangkan, oleh karenanya diperoleh hhasil bahwa media yang dikembangkan dapat dikategorikan sebagai multimedia pembelajaran yang efektif.

\section{Simpulan}

Hasil dari penelitian dan pengembangan ini dinyatakan layak oleh ahli materi dan ahli media. Aspek tampilan memperoleh rata-rata nilai 3,93 dengan kategori baik, aspek pemrograman memperoleh nilai rata-rata 4,08 dengan kategori baik, aspek pembelajaran memperoleh ratarata nilai 4,20 dengan kategori baik serta aspek isi memperoleh rata-rata nilai 4,20 dengan kategori baik.

Produk multimedia yang dikembangkan juga memiliki penilaian efektif dalam meningkatkan sikap cinta tanah air dan peduli lingkungan terbukti dari hasil uji mann whitnet test dengan nilai rata-rata 335,96 untuk siswa yang tidak menggunakan media dan 1107,93 untuk siswa yang menggunakan media. Sedangkan untuk hasil uji sikap peduli lingkungan diperoleh rata-rata nilai 298,52 untuk yang tidak menggunakan media dan 944,20 siswa yang menggunakan media. Data tersebut membuktikan bahwa media yang dikembangkan secara efektif dapat meningkatkan sikap cinta tanah air dan peduli lingkungan pada siswa kelas V di Gugus Gajah Mada, Desa Kandangmas, Kecamatan Dawe, Kabupaten Kudus.

\section{Daftar Pustaka}

Aminrad, Z., Azizi, M., Wahab, M., Huron, R., \& Nawawi, M. (2010).

Environmental awareness and attitide among iranian students in Malaysian universities. International Journal Environment Asia, 3(1), 1-10. doi:https:// doi.org/10.14456/ea.2010. 34.

Azwar, S. (2007). Sikap manusia. Yogyakarta: Pustaka Pelajar.

Borg, W. R., \& Gall, M. D. (1983). Education research an introduction. New York: Longman Inc.

Chen, C. Y., \& Chung, W. L. (2011). Research on the learning effects of multimedia assisted instruction on mandarin vocabulary for Vietnamese students: A preminary study involving e-learning system. Educational Research Reviews, 6(17), 919-927.

Evans, C., \& Gibbons, N. J. (2007). The interactivity effect in multimedia learning. Computers $\mathcal{E}$ Education Journal, 49(4), 1147-1160. 
doi:https:// doi.org/10.1016/j.comped u.2006.01.008.

Gagne, K. M., Briggs, L. J., \& Wager, W. W. (1992). Principles of instructional design, $4^{\text {th }}$ edition. Orlando: Harcourt Brace Jovanovich publisher.

Harrington, N. G., Giles, S. M., Hoyle, R. H., Feeney, G. J., \& Yungbluth, S. C. (2001). Evaluation of the All Stars character education and problem behavior prevention program: effects on mediator and outcome variables for middle school students. Health Education and Behavior, 28(5), 533-546. doi:https:// doi.org/10.1177/10901981 0102800502.

Kemendikbud. (2011). Pedoman pelaksanaan pendidikan karakter kementerian pendidikan dan kebudayaan. Jakarta: Kemendikbud.

Kusano, K., Frederiksen, S., Jones, L., Kobayashi, M., Mukoyama, Y., Yamagishi, T., ... \& Ishizuka, H. (2013). The effects of ICT environment on teachers' attitudes and technology integration in Japan and the US. Journal of Information Technology Education: Innovations in Practice, 12, 29-43.

Lewis, S. V., Robinson III, E. H., \& Hayes, B. G. (2011). Implementing an authentic character education curriculum. Journal of Clidhood Education, 87(4), 227-231. doi:https:// doi.org/10.1080/00094056 .2011.10523183.

Munir. (2009). Pembelajaran jarak jauh berbasis teknologi informasi dan komunikasi. Bandung: Alfabeta.

Muzanni, A., \& Muhyadi, M. (2016). Pengembangan perangkat pembelajaran problem solving mata pelajaran IPA terhadap hasil pembelajaran kognitif siswa SD. Jurnal Prima Edukasia, 4(1), 1-11. doi:https:// doi.org/10.21831/jpe.v4i1 .7746 .
Naim, N. (2012) Character buliding optimalisasi peran pendidikan dalam pengembangan ilmu $\mathcal{E}$ pembentukan karakter bangsa. Yogyakarta: ArRuzz Media.

Nudji. (2015). An Effort to enhance sense of nationalism for students of senior hight school through Pendidikan Pancasila dan Kewarganegaraan (PPKn). Academic Research International, 6(1), 405-411.

Purnomo, H., \& Wilujeng, I. (2016). Pengembangan bahan ajar dan instrumen penilaian IPA tema indahnya negeriku penyempurnaan buku guru dan siswa kurikulum 2013. Jurnal Prima Edukasia, 4(1), 67-78. doi:https:// doi.org/10.21831/jpe.v4i1 .7697 .

Sakat, A. A., Zin, M. Z. M., Muhamad, R., Ahmad, A., Ahmad, N. A., \& Kasmo, M. A. (2012). Educational technology media method in teaching and learning progress. American Journal of Applied Sciences, 9(6), 874-878. doi:https:// doi.org/10.3844/ajassp.20 12.874.878.

Seels, B. B. \& Richey, R. C. (1994). Instructional technology: The definition and domains of the field. Washington, DC:AECT.

Surjono, H. D. (2017). Multimedia pembelajaran interaktif: konsep dan pengembangan, edisi pertama. Yogyakarta: UNY Press.

Suryansah, T., \& Suwarjo, S. (2016). Pengembangan video pembelajaran untuk meningkatkan motivasi dan hasil belajar kognitif siswa kelas IV SD. Jurnal Prima Edukasia, 4(2), 209221.

doi:https:// doi.org/10.21831/jpe.v4i2 .8393 .

Susanto, B. (2008). Gemerlap Nasionalitas postkolonial. Yogyakarta: Kanisius. 
Sutopo, H. A. (2003). Multimedia interaktif dengan flash. Yogyakarta: Graha Ilmu.

Walgito, B. (2002). Psikologisosial (suatu

pengantar). Yogyakarta: Andi Offset. 